\title{
THE ROLE OF THE INTEGRATING FACTOR IN THE SHAPING OF TRANSBORDER CO-OPERATION: THE CASE OF POLAND*
}

\author{
Sylwia DoŁZBŁasz, AndrZej RaczyK \\ University of Wrocław, Institute of Geography and Regional Development, Department of Spatial \\ Management, Wrocław, Poland
}

Manuscript received July 26, 2010

Revised version October 25, 2010

DoŁZBŁASZ S., RACZYK A., The role of the integrating factor in the shaping of transborder co-operation: The case of Poland. Quaestiones Geographicae 29(4), Bogucki Wydawnictwo Naukowe, Poznań 2010, pp. 65-73, 2 figs. DOI 10.2478/v10117-010-0032-3, ISBN 978-83-62662-30-2, ISSN 0137-477X.

ABSTRACT. Transborder co-operation is shaped by many factors and thus takes various forms on particular borders. Within the same formal-legal arrangements under Interreg Programmes, the greatest role in the diversification of co-operation was played by non-system-related conditions specific to particular border regions. To identify what specifically drives co-operation, the nature of Polish-German and Polish-Czech transborder co-operation was compared. On the basis of the research conducted, it can be said that the existence of similar conditions on both sides of the border may define specific directions of co-operation and hence be called an integrating factor. Coupled with relatively weak barriers, this integrating factor may exert a powerful influence on the development and character of transborder co-operation. Thus, in the process of shaping co-operation policy it is crucial to identify the existing integrating factor (or to define the possibilities of creating it) and to limit the impact of co-operation barriers.

KEY WORDS: transborder co-operation, border regions, Interreg Programmes, integrating factor

Sylwia Dotzbtasz, Andrzej Raczyk, Department of Spatial Management, Institute of Geography and Regional Development, University of Wroctaw, Pl. Uniwersytecki 1, 50-137 Wroctaw, Poland; e-mail: sylwia.dolzblasz@uni.wroc.pl, andrzej. raczyk@uni.wroc.pl

\section{Introduction}

It is commonly known that transborder cooperation is shaped by many factors and thus takes various forms on particular borders. It is, however, very difficult to assess the significance of each factor since the complexity of conditions affecting those factors makes simple comparisons of border regions virtually impossible. This is further aggravated by the fact that their impact tends to change in time while new ones emerge. This concerns both the European Union as a whole and individual countries. Poland is no exception. Its accession to the EU in 2004 brought about a significant change in the institutional setting and formal-legal framework of co-operation (system-related settings). This particularly affected one specific form of co-operation, viz. that under programmes financed from the EU funds (Interreg IIIA, ETC). The change was accompanied by the creation of systemic arrangements virtually homogeneous at the national scale.

* A research paper financed from the 2009-2011 budget under the Ministry of Science and Higher Education project No 4299/PB/IGRR/09 entitled: "The shaping of co-operation and competition relationships in the Polish-German border regions as part of European integration". 
Therefore, the greatest role in the diversification of co-operation in border regions was played by external, non-system-related conditions specific to particular regions. This facilitates comparisons of the border regions and in consequence helps to identify the significance of particular factors in the shaping of co-operation, making it possible to establish which situations and specific factors may substantially modify the character of co-operation. In other words, co-operation may take significantly different forms even within the same formal framework. This stems from the assumption that homogeneous conditions translate into a homogeneous character of co-operation.

The purpose of this paper was to analyse the determinants and effects of transborder cooperation. As regards the determinants, special attention was paid to similarities and differences between them. An attempt was also made to identify what specifically drove co-operation, the factors generating, driving or determining the character of transborder co-operation in particular border regions.

The empirical research was carried out on Poland's western and southern borders. It was based on an analysis of a total of 403 projects implemented under the Community Initiative Programme Interreg IIIA 2004-2006. This means that the research encompassed formal co-operation. It seems, however, that it well reflects the actual activity of the main actors of the borderland. It is worth mentioning that transborder co-operation is also shaped by its informal dimension (Stryjakiewicz 1998).

\section{System-related determinants of transborder co-operation}

Intensive development of institutional forms of co-operation in the Polish-German and PolishCzech borderland started with the political transformation of the 1990s resulting from the political, economic and social changes which took place in Poland and its neighbouring countries then. As elsewhere, this also reflected the intensification of integration processes in Europe (the first Community Initiative Programme Interreg and its subsequent editions) (Perkmann 1999; Church \& Reid 1996). At that time, co-operation was based on bilateral agreements between Poland and Germany as well as Poland and the Czech Republic. Poland's ratification of the Madrid Convention ${ }^{1}$ (1993) and the European Charter of Local SelfGovernment $^{2}$ (1994) provided a strong impetus to develop co-operation at the regional and local levels, while also increasing the possibility of grass-roots initiatives. The introduction of local self-government in $1990^{3}$ was also significant in this context. This situation led to the creation of Euroregions in border areas. The first Euroregions were created in the Polish-German and PolishCzech borderland; they had a grass-roots character. In the pre-accession period they became the main centres for the establishment and growth of co-operation (Ciok 2004). It was reinforced by the availability of EU funds under the PHARE CBC programme and its subsequent editions: on the western border, since 1994, and on the PolishCzech border, since 1995, first under a PolandGermany-Czech Republic trilateral programme and since 1999 under bilateral programmes. The institutional setting was therefore similar on both borders, with the western border having a slightly longer history of such co-operation. A much more important differentiating element was the volume of EU funds allotted to transborder cooperation projects. There was a clear dominance of the western border (EUR $450 \mathrm{~m}$ ) over the southern one (EUR $23 \mathrm{~m}$ ). As the possibility of obtaining financial support was a significant stimulus to undertaking such activities, the development of co-operation in the Polish-German border region was much more intensive both in terms of the number of joint initiatives and their worth.

The accession of Poland and the Czech Republic to the EU in 2004 led to the implementation of the Community Initiative Programmes

1 European Outline Convention on Transfrontier Cooperation between Territorial Communities or Authorities (adopted by the Council of Europe at the Madrid conference on 21 May 1980), Law Gazette of 10 July 1993/6, item 287.

2 European Charter of Local Self-Government, Law Gazette of 1994/124, item 607, passed by the Council of Europe in 1985, came into effect in 1988.

3 Territorial Self-Government Act of 8 March 1990 (Law Gazette of 1990/16, item 95). The act has often been amended and is now called the Commune Self-Government Act (Law Gazette of 2001/142, item 1591, with amendments). 
Interreg IIIA in both border regions. The institutional settings of co-operation and the implementation system were radically changed at that time (Dołzbłasz \& Raczyk 2010) while remaining similar in both border regions. The adopted solutions regarding the allocation of funds resulted in the continuation of financial disproportions, though they became less acute (EUR $86.6 \mathrm{~m}$ and $18 \mathrm{~m}$, respectively).

The basic elements of system-related settings on both sides of the border regions are:

- similarity of institutional structures,

- differences in the accessibility of funds, and

- dominance of similarities in the key assumptions of co-operation programmes.

\section{Non-system-related determinants of transborder co-operation}

When analysing determinants of the role of the state border, it needs to be remembered that although its obvious material implications are important, a borderland is shaped by a whole set of cultural, historical and political interactions and processes occurring within its space (van Houtum 1999).

On the western border, the most important natural characteristic is the shape of the state border. The border runs along the Oder and the Lusatian Neisse. This barrier significantly limits a free flow of people and goods, and overcoming it would require considerable financial outlays, mainly for the construction of bridges. For this reason the total number of places in which one can cross the border is small in relation to its length. The formal closure of border crossings after Poland's accession to the Schengen Zone in December 2007 increased its permeability only slightly due to its riverine character and the small number of bridge crossings. The only exception was its northern section (land border). It is worth noting that the dividing river could be an important incentive for co-operation, e.g. in the fields of environmental protection, prevention of natural disasters, economic use, the development of Oder-based tourism, and spatial planning.

On the Polish side the connectivity of the road network is relatively low. This makes travelling along the border difficult, and together with the shortage of bridges significantly limits the possibility of crossing the border.

Environmental factors may also play some role in initiating co-operation, in particular the existence of large, compact forest complexes and lakelands in the border region. This enhances tourist attractiveness of the region and is an incentive to co-operate in the field of tourism and undertake activities connected with environmental protection. In this context one should underline the importance of the Baltic Sea coast, which is a significant tourist region while being an area with no border barrier. The Szczecin Lagoon must also be mentioned here as a shared basin with logistic and tourist potential.

As far as socio-economic determinants are concerned, differences in the level of socio-economic development between the areas on the two sides of the border seem very important. In the Polish-German borderland the recorded economic disproportions are among the biggest in the EU (see ESPON Atlas 2006). Moreover, the socioeconomic situation in both Polish and German border regions is much worse than in the centre of the countries (a lower level of infrastructural development, a higher unemployment rate). This is the result of their peripheral location.

Although the cultural barrier still has a historically conditioned impact, its significance seems to be decreasing (national stereotypes, perception of the neighbours, lack of language competence, negative historical experiences, cultural differences) (Krätke 2002). The fact that the inhabitants of the border regions are immigrants (and their descendants) seems important and is reflected in the level of social capital, the sense of territorial identity (local and regional identity) and social involvement. These features are at a relatively lower level in the western part of the border region (with the exception of areas standing out for their local activity, which is a sign of considerable potential as regards social activation). This usually has a negative impact on transborder cooperation. As in the case of the above-mentioned factors, it seems that also this barrier should decrease with time.

In the areas adjacent to Poland's western border the settlement network on either side of the border is not dense and the level of urbanisation (especially in its middle part) is also quite 
low. This may form a barrier to (but in terms of natural and tourist attractiveness also an impulse for) co-operation. In the absence of other large urban centres, Berlin exerts a strong impact, and Szczecin to a lesser degree. Moreover, due to their specific character, the divided towns at the Polish-German border could become important centres of transborder co-operation.

In economic terms, neither the Polish nor the German border area plays a significant role in the respective country's economy (Krätke 2002). With the exception of a few areas of increased economic activity, the activity level is low (Szczecin and its surroundings, to a lesser extent Frankfurt an der Oder, Cottbus, and the region of the Turoszów Sack with its active mining industry on the Polish side and the problematic post-mining area currently undergoing redevelopment) (see Harfst et al. 2009).

The main determinants of transborder cooperation in the Polish-Czech border region are undoubtedly environmental factors. The state border is mountainous for the most part. Its considerable part consists of mountains and foothills. This is closely connected with natural attractions (a high proportion of protected areas, including those belonging to the Natura 2000 network). Apart from natural values, there are also numerous man-made ones which enhance the region's tourist attractiveness.

Apart from its positive aspects, the mountainous location also generates negative effects, the biggest of which is a transit barrier. In this context the number of transport connections is crucial the number of road connections is relatively high (though few of the roads are good quality), there is definitely not enough railway connections, and the number of tourist connections (walking trails) is satisfactory. Poland's and the Czech Republic's accession to the Schengen Zone is very important. The possibility of crossing the border in a place of one's choice creates favourable conditions for setting up new transport connections (probably at an early stage pedestrian and bike crossings, but in subsequent years also road connections should follow). This seems to have a positive influence on the development of transborder tourism.

Another positive factor is a similar level of socio-economic development of the Polish and Czech parts of the border area. Similarities do not end here - they involve the economic structure, e.g. the existence of mining / post-mining areas (Belof et al. 2008), restructuring of traditional branches of industry, a search for new development impetus, an increase in the importance of the service sector, etc.

However, problems appear on both Polish and Czech sides. They mostly result from the peripheral location, a relatively low level of socio-economic development and infrastructural management in mountainous areas as well as antiquated industry and depopulation processes. This creates a co-operation barrier due to e.g. giving higher priority to other issues and perceiving the neighbours as competition. However, this similarity of problems can also lead to co-operation in order to overcome them.

The Polish-Czech border areas are characterised by a high level of urbanisation (a much denser settlement network, especially among small and medium-sized towns) and a higher level of industrialisation (both on the Polish and Czech sides).

A positive feature in terms of transborder cooperation development has also been a lack of strong negative stereotypes and a good attitude towards the neighbouring nations. An additional favourable factor is a less negative historical heritage. Immigrants (and their descendants) predominate in most of the border area, which may constitute a co-operation barrier for reasons similar to those in the Polish-German border region (here, too, this barrier seems to diminish with time).

On the basis of the analysis of conditions, we can distinguish two crucial elements affecting cooperation: similarity /difference and the occurrence and strength of barriers ${ }^{4}$.

It seems that wide differences constitute an important factor hindering co-operation. This results, among other things, from different expectations concerning potential co-operation, possibilities of undertaking particular activities, and development objectives in the given areas. It may lead to an asymmetry in relations between the cooperating partners where one side is perceived as

4 It is worth noting at this point that complete closure of border barriers may lead to a decline in interactions between the inhabitants of both sides of the border in everyday life (Spierings \& van der Velde 2008). 
"inferior" (a petitioner-benefactor relationship), especially in terms of economic development. This disproportion may also manifest itself in the level of interest in co-operation (an interested party - uninterested party relationship). The existence of similarities on both sides of the border is definitely much more favourable: problems as well as possibilities and expectations might prove to be similar, which has a positive influence on undertaking joint activities. Moreover, relations between the co-operating parties are better in the case of a relative symmetry.

A negative factor in transborder co-operation is the functioning of the state border as a barrier in many dimensions, e.g. to the flow of people, goods, information, as a cultural barrier, etc. The stronger it is, the harder the co-operation. In the case of the Polish western and southern borders, which are also internal borders of the Schengen Zone, formal barriers do not exist; rather, barriers are created by environmental factors. The river constituting the western border in practice turns out to be a greater obstacle than the mountains at the southern border. It appears that positive effects of being a part of the Schengen Zone will be much more noticeable in the southern border region.

\section{Grounds for co-operation on the Polish western and southern borders}

The adopted solutions of implementation of transborder co-operation programmes under Interreg IIIA were generally very similar. This means that the institutional setting did not deeply affect the character of co-operation within each programme (Dołzbłasz \& Raczyk 2007). Therefore, it was the local arrangements that played an important role in this context because, under specific conditions, they can determine the shape of co-operation.

At the western border, projects that dominated in the generic structure were those of social infrastructure (about 22\%) (Fig. 1). They were mainly connected with the construction and modernisation of recreational-sports-didactic facilities and equipment as well as community centres in a broad sense. At the Polish-Czech border such projects constituted merely one-third of the western figure (under $8 \%$ ).

A very important role in co-operation was played by road investments, with more of them at the southern border (nearly 16\%) than at the western one (about 12\%). The proportion of projects connected with sewage infrastructure was significant and comparable (about 6\% at each).

The implemented projects were dominated by infrastructural ventures. Despite the large number of available intervention categories, a vast majority of them was chosen very rarely. Beneficiaries' preferences were noticeable and concentrated on a few main types of activity (e.g. community centres, roads, sewage systems). There were very few projects in categories important from the point of view of socio-economic development and the creation of transborder connections, e.g. research, technical progress and innovative activities, support for SMEs development, or adaptation and development of rural areas.

A characteristic feature clearly distinguishing the Polish-Czech border region from other such regions in the country was the dominance of tourism-oriented ventures. While the proportion of tourist facilities contributed was comparable in both border regions, in the remaining tourismrelated categories the differences were significant (in particular in joint services for the tourism industry) (Fig. 1). There was a pronounced lack of human resources projects, very common, in turn, at the western border. As far as scientific-research projects are concerned, the situation was reversed (a clear dominance of the southern border).

In the Polish-Czech border region "soft" projects played an important role. They had a great transborder effect (e.g. projects designed to create an integrated information system and tourist promotion, the creation of an integrated network of tourist trails, bike trails and pistes, promotion of joint regional products). This fact allows an assessment of the generic structure of ventures as relatively favourable, especially as the percentage of scientific-research projects was higher than in the Polish-German border region (e.g. co-operation between universities in the field of research into energy utilisation, the creation of a logistic infrastructure model in the border region, or citizen participation and tolerance 


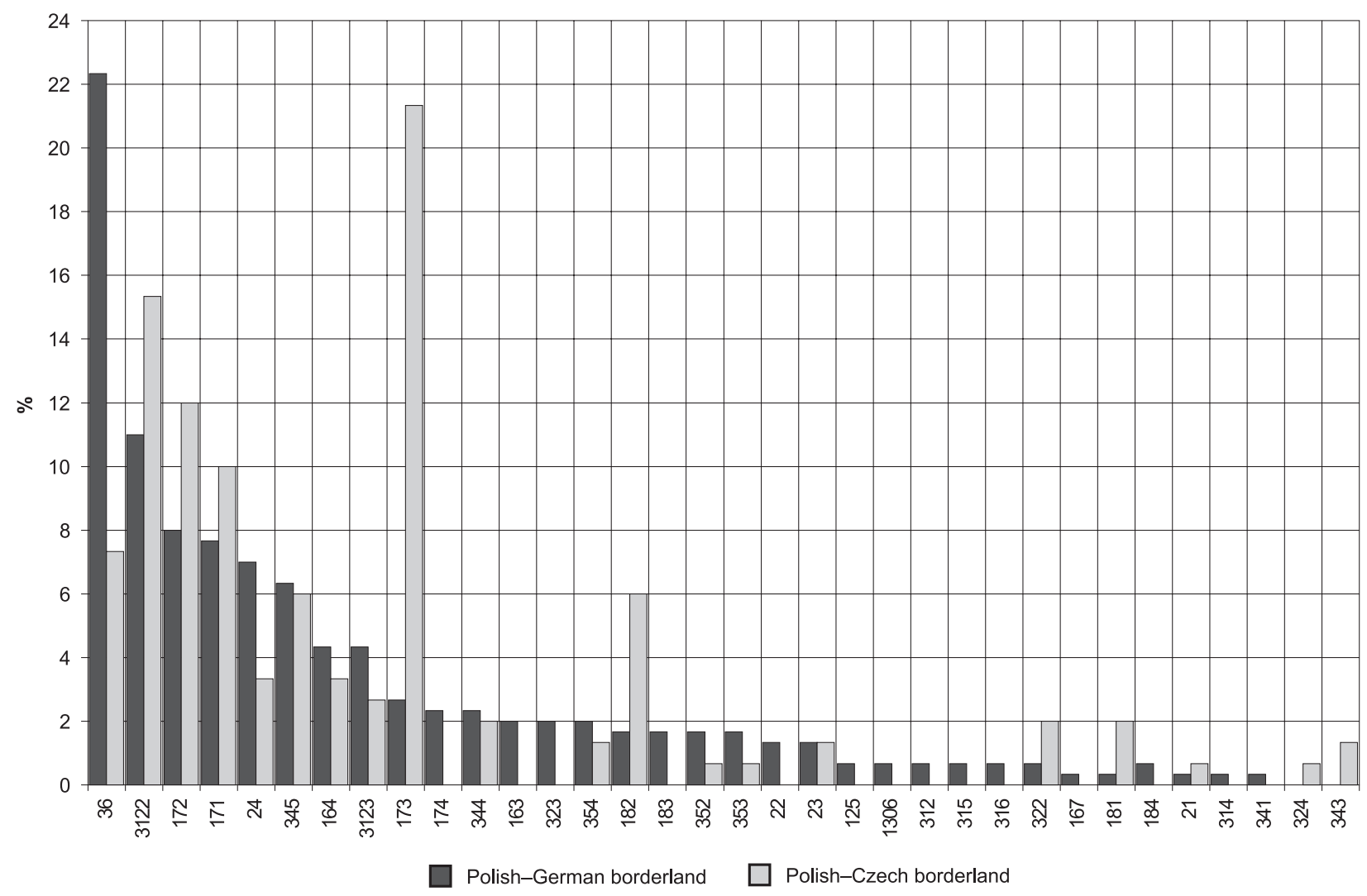

Areas of intervention by category (OJ L 63, 3.3.2001): 125 Restoring forestry production; 1306 Renovation and development of villages; 163 Business advisory services; 164 Shared business services; 167 SME vocational training; 171 Tourism, physical investment; 172 Tourism, non-physical investment; 173 Shared services for the tourism industry; 174 Tourism-specific vocational training; 181 Research projects based in universities and research institutes; 182 Innovation and technology transfers; 183 RTDI Infrastructure; 184 Training for researchers; 21 Labour market policy; 22 Social inclusion; 23 Developing educational and vocational training; 24 Workforce flexibility; 312 Roads; 3122 Regional/local roads; 3123 Cycle tracks; 314 Airports; 315 Ports; 316 Waterways; 322 Information and communication technology; 323 Services and applications for the citizen; 324 Services and applications for SMEs; 341 Environmental infrastructure (air); 343 Urban and industrial waste; 344 Drinking water; 345 Sewerage and purification; 352 Rehabilitation of urban areas; 353 Protection, improvement and regeneration of the natural environment; 354 Maintenance and restoration of the cultural heritage; 36 Social and public health infrastructure

Fig. 1. Number of projects implemented in the Polish borderland within the framework of the Community Initiatives Interreg IIIA 2004-2006 by intervention category.

Source: own presentation based on the data of the Ministry of Regional Development.

of local communities). The greater involvement of research institutions in projects with Czech partners probably resulted from the fact that international co-operation between Polish and Czech institutions was easier to implement than between Polish and German ones. Apparently, it could have been caused by similar functioning of the scientific sector and much smaller discrepancies in the level of technical advancement or technical equipment. Moreover, one has to stress the positive role of the region's policy, which promoted and supported international co-operation of scientific-research centres from Opole.

When analysing the spatial distribution of particular projects, we can observe a clear dominance of cities. Such a distribution indicates that cities were the main bonds of co-operation. On the western border the ventures can be seen to be situated in the biggest cities of the Polish border region, primarily in Szczecin, and to a lesser degree in Zielona Góra, Gorzów Wielkopolski, Zgorzelec, Jelenia Góra and their immediate surroundings. The factor of border closeness played a relatively small role, noticeable only in the case of the main border crossings. The present spatial distribution of projects in the border area may be a sign of the greatest readiness of institutions from this area for a quick preparation of appropriate applications. This may reflect the level of human and social capital development. A clear interdependence (in spatial terms) between the size of the particular units and their administrative status and the volume of ventures implemented may suggest a difficulty in accessing structural funds. 
On the southern border the main factor shaping the spatial distribution of implemented projects was the closeness of the border. However, the spatial concentration characteristic of the Polish-German border area was not observed here. An important role in the spatial distribution was played by tourist attractiveness of particular regions and the existence of spas (the Table Mountains, the Karkonosze Range). A surprisingly small role in the shaping of co-operation was played by Jelenia Góra and Wałbrzych, which should be highly attractive thanks to their location.

Projects in both border areas were implemented in fewer than one-third of the communes. This relatively small proportion can be explained by the allocated funds being too small for the area covered by support. Consequently, funds were only allocated to the best ventures and institutions which had sufficient funds to finance them.

The structure of beneficiaries was very similar: it was dominated by territorial self-government units (about 70\%), mainly communes (about $55 \%$ ), with a small share of associations (about $6 \%)$, cultural institutions (4-5\%) and government administration (2-3\%). In the Polish-German border region schools were quite active (about 6\%), and in the Polish-Czech region, scientific institutions (about 9\%).

\section{The integrating factor}

When transborder co-operation programmes are implemented in a number of border regions within one institutional system (e.g. Interreg) under the same formal conditions, the character of co-operation is mainly shaped by the local factors. Factors specific to a particular border region play an important role and may shape joint ventures implemented in this area. These factors, combined with relatively weak barriers, are an element shaping the co-operation impetus, boosting its development and enhancing its quality.

Typically, transborder co-operation is affected by many factors. In most cases, however, it is clear that some of them play a crucial role. They mould the character of co-operation, give it a form, trigger local initiatives, and stimulate actors to undertake joint activities.
The existence of similar conditions on both sides of the border may define specific directions of co-operation and thus be called an integrating factor. This integrating factor may exert a powerful influence on the development (dynamics) and character of transborder co-operation. In practice, its effect is determined mainly by the role of the border as a barrier - the weaker the barrier, the greater the possibility of using the integrating factor. In the process of shaping co-operation policy a crucial role should be played by the identification of the existing integrating factor and the limitation of the impact of co-operation barriers. In the absence of such a factor it would be essential to seek possibilities of creating one, e.g. by looking for common, similar fields of interest at a larger or smaller scale (e.g. ecological products, the job market, tourist management, culture). It must be remembered that the existence of a strong integrating factor may lead to the limitation of co-operation to one aspect only and may unfavourably affect its quality. It should be stressed, however, that the lack of this factor does not rule out the development of transborder cooperation, but would require different ways of shaping it. The same determinants may hinder co-operation and favour it at the same time, e.g. at the Polish-German border historical determinants constitute a barrier to co-operation on the one hand, but on the other they also stimulate it (joint cherishing of the cultural heritage, sentimental tourism, etc.). By the same token, low population density and a poorly developed settlement network in forest regions and lakelands may lead to co-operation in the field of tourism and environmental protection. The above conclusions also apply to informal co-operation, but the confirmation of this assumption requires a separate research.

It seems that the evolution of transborder cooperation in border areas goes through the following stages (provided that the determinants are, or can be, similar) (Fig. 2):

- In the first stage, when the state border is a very strong barrier irrespective of the existing determinants, the activity based on them is autonomous on both sides of the border. This means that in both situations, i.e. when the determinants, e.g. environmental factors, are similar (1a), and when they are different, 


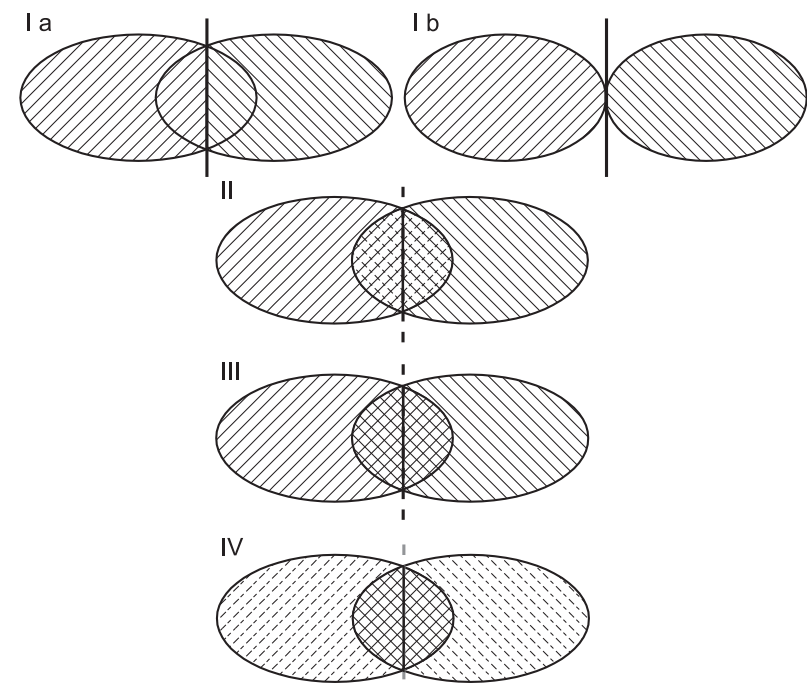

Fig. 2. Determinants of transborder co-operation as the integrating factor.

Source: own presentation.

e.g. the legal systems (1b), no joint activities are undertaken.

- As a result of a weakening of the state-border barrier, the similarity of determinants may become grounds for joint activities (the beginning of a co-operation relationship). This concerns both independent and dependent ${ }^{5}$ joint determinants. Dependent determinants, even if initially different on the two sides of the border, may become similar, e.g. through changes in the legal and economic systems resulting from integration processes. Activities can be undertaken in order to create new, common determinants which would form grounds for co-operation, e.g. the shaping of a common "borderland" identity, common elements of the cultural heritage, common infrastructure.

- In the third stage, the co-operation relationship intensifies as a result of using the determinants. It should be emphasised that reaching stage three may be a sign of a border area having become a transborder region.

- In the fourth stage, the relations in the border region may be stronger than in the neighbouring area due to the impact of many common determinants and their synergy as well as a very weak influence of the border barrier. This stage seems to be highly hypothetical and very difficult to achieve in the Polish context.

5 The authors understand this notion as determinants which can be modified, e.g. the legal system, the level of development, etc.
Wide disparities in the determinants do not exclude the development of co-operation, but they probably make this co-operation work differently and be more likely to be instrumentalised (e.g. as a chance to obtain EU funds) (Jańczak 2008).

The structure of projects implemented under Interreg IIIA programme in the Polish-Czech border region clearly confirms the impact of the integrating factor. These are environmental factors which determine the character of co-operation (development of transborder tourism). However, it is impossible to assess to what extent this results from the actual needs of the local communities, and to what extent, from lack of alternatives to socio-economic development. The clear specificity of the co-operation, despite the homogeneous rules and structures of Interreg IIIA implementation at the national scale, seems to be a positive phenomenon as it combines the general purpose of this programme (the development of transborder co-operation) with already existing, real chances of local development (tourism).

The Polish-German border region has got no one definite motto of co-operation which could determine its nature. Although this region has the longest history of co-operation financed by the EU (Phare CBC and Interreg IIIA programmes) and accounts for the greatest amount of funds allocated for this purpose, it seems that co-operation is still not much advanced. It can be assumed that the reason for this situation is the lack of an integrating factor, which results in the lack of strong co-operation impetus. Activities undertaken so far have mainly concentrated on the development of infrastructure and contributed little to the formation of this factor. Due to the size of the border region and its internal diversification, the identification of one integrating factor might prove very difficult. It appears that co-operation policy should focus on searching for many such factors with a local or a regional impact, e.g. the specificity of the divided towns, the potential of the Oder, the coast and the Szczecin Lagoon, the common (however difficult) cultural heritage, environmental protection, etc.

In view of the above, we can identify the existence of a relatively strong integrating factor on the southern border. On the western border, however, co-operation was largely shaped by institutional pragmatism. 


\section{Summing up}

A similarity of problems and objectives of socio-economic development can deeply affect cooperation. The lack of strong barriers connected with state borders is crucial. The appearance of the integrating factor depends on the co-existence of those two elements. Its emergence may significantly shape the development of transborder cooperation and deeply influence its nature. At the same time lack of a clear integrating factor does not rule out the possibility of creating a cohesive transborder region, but co-operation policy must then be carried out on many different platforms.

It seems that the stakeholders in the border regions should not only focus on co-operation under the given conditions, but also consciously create them. The shaping of new conditions should take into consideration potential integrating factors. Therefore, it is crucial to popularise the awareness of real barriers and co-operation development potential among all co-operating actors. This especially applies to situations where there are no strong external integrating factors (e.g. environmental), and the activities undertaken attempt to create them (e.g. cultural identity, the job market).

"Every state border, every border region, is unique" (Anderson \& O'Dowd 1999). The existence of integrating factors also indicates that there is no single, universal pattern of transborder cooperation development. Each border region must find its own, unique dimension of this co-operation. Therefore, the planning of co-operation development within the regional policy of the European Union as well as particular states should only outline overall aspects of this policy and be highly flexible in the selection of instruments and directions of co-operation development.

\section{References}

ANDERSON J. \& O'DowD L., 1999. Borders, border regions and territoriality: Contradictory meanings, changing significance. Regional Studies, 33 (7): 593-604.

Belof M., Mironowicz I., Mlek M., Zipser T. \& PolańsKi T., 2008. Uwarunkowania rozwoju przestrzennego Polski wynikające z sąsiedztwa z republiką Czech (Determinants of spatial development of Poland resulting from the neighbourhood of the Czech Republic). Ekspertyzy do KPZK 2008-2033, t. III, Ministerstwo Rozwoju Regionalnego, Warszawa: 233-274.

Church A. \& ReID P., 1996. Power, international networks and competition: The example of cross-border co-operation. Urban Studies, 33 (8): 1297-1318.

CıOK S., 2004. Pogranicze polsko-niemieckie. Problemy wspótpracy transgranicznej (Polish-German borderland. The issues of cross-border co-operation). Wydawnictwo Uniwersytetu Wrocławskiego, Wrocław.

DoŁzBŁAsz S. \& RACZYK A., 2007. New versus old cross-border co-operation programmes in the example of Polish-Czech and Polish-German border areas. Europa XXI, 16, Regional development in Central Europe - cohesion or competitiveness, IGiPZ PAN, PTG, Warszawa: 153-165.

DoŁzBŁASZ S. \& RACZYK A., 2010. Wspótpraca transgraniczna w Polsce po akcesji do UE (Transborder co-operation in Poland after accession to the EU). Wolters Kluwer Polska, Warszawa.

ESPON Atlas. Mapping the structure of the European territory. 2006, Bonn

Harfst J., Wirth P. \& Lintz G., 2009. Scientific concept of the ReSOURCE Project - "Roadmap", 2010. Leibniz Institute of Ecological and Regional Development, Dresden.

JAŃcZAK J., 2008. Polsko-niemieckie regiony transgraniczne i miasta transgranicze po 2004 roku. Pomiędzy pragmatyzmem instytucjonalnym a izolacją społeczną (Polish-German transborder regions and towns after 2004. Between institutional pragmatism and social isolation). In: Dołzbłasz S. \& Raczyk A. (eds), Przekształcenia regionalnych struktur funkcjonalno-przestrzennych. Europa bez granic - nowa jakość przestrzeni. Wrocław, Instytut Geografii i Rozwoju Regionalnego Uniwersytetu Wrocławskiego, 2008: 93-100.

KRÄTKE S., 2002. The regional impact of EU eastern enlargement: A view from Germany. European Planning Studies, 10 (5): 651-664.

PERKMANN M., 1999. Building governance institutions across European borders. Regional Studies, 33 (7): 657-667.

SPIERINGS B. \& VAN DER VELDE M., 2008. Shopping, borders and unfamiliarity: Consumer mobility in Europe. Tijdschrift voor Economische en Sociale Geografie, 99 (4): 497-505.

STRYJAKIEWICZ T., 1998. The changing role of border zones in the transforming economies of East-Central Europe: The case of Poland. GeoJournal, 44 (3): 203-213.

VAN Houtum H., 1999. Internationalisation and mental borders. Tijdschrift voor Economische en Sociale Geografie, 90 (3): 329-335. 